\title{
STUDIE VERBÁLNÍ PRODUKCE ČESKÝCH PŘEDŠKOLNÍCH DĚTÍ S VÝVOJOVOU DYSFÁZIÍ
}

Alžběta Větrovská Zemánková \& Gabriela Seidlová Málková

\begin{abstract}
Abstrakt
Tato studie si klade za cíl prozkoumat rozsah produktivní slovní zásoby a kvalitu vyjadřování u českých monolingvních dětí s vývojovou dysfázií ve srovnání s dětmi intaktními v době před nástupem do prvního ročníku základní školy. K výzkumnému šetření byl vytvořen původní test aktivní slovní zásoby zaměřený na substantiva, adjektiva a verba. Výsledná data ukazují, že oba sledované aspekty verbální produkce se mezi výzkumnými skupinami statisticky významně liší a lze mezi nimi vysledovat velmi těsný korelační vztah. Při podrobnějším zkoumání rozsahu slovní zásoby u jednotlivých slovních druhů se ukázalo, že nejvíce se tento rozsah mezi skupinami participantů liší u adjektiv a nejméně u substantiv.
\end{abstract}

Klíčová slova: vývojová dysfázie, lexikální schopnosti, testování slovní zásoby

\section{A STUDY ON THE SPECIFIC-LANGUAGE-IMPAIRED CZECH PRESCHOOL CHILDREN'S VERBAL PRODUCTION}

\begin{abstract}
This study aims to analyse a range of the productive vocabulary and quality of verbal expression in Czech monolingual specific-language-impaired (SLI) preschool children. SLI children's production was also compared to a verbal production of typically developing (agematched) peers. An assessment tool was developed to measure the range and the quality of children's production of nouns, verbs and adjectives. Both aspects of verbal production (the range and the quality) were also proved to be closely correlated. Research results reveal statistically significant differences between the SLI and a comparison group at both range and the quality of verbal expression. A more detailed examination shows that the differences between SLI and typically developing children's production manifest themselves in the usage of adjectives the most and the least in the usage of nouns.
\end{abstract}

Key words: specific language impairment, lexical skills, productive vocabulary assessment

Došlo: 30. 12. 2019

Schváleno: 5. 10. 2020 


\section{Úvod}

Rozsah slovní zásoby je důležitým indikátorem a užitečným měřítkem mentálního vývoje předškolního dítěte. Její dostatečná úroveň představuje jeden z předpokladů úspěšného vzdělávání dítěte. Má významnou úlohu v rozvoji čtenářských dovedností, zejména ve vývoji porozumění čtenému (Caravolas et al., 2019; Seidlová Málková \& Smolík, 2014). Děti se sníženými schopnostmi v oblasti verbální exprese, v níž se projevuje aktivní slovní zásoba, jsou ze strany pedagogů zpravidla hodnoceny hưře než jejich vrstevníci bez těchto nedostatků (Durdilová \& Klenková, 2014). Hodnocení slovní zásoby u dětí v předškolním věku má tedy nezpochybnitelný význam. Pro tyto účely je ale třeba mít dostupný a přehledný diagnostický materiál.

Deficity ve slovní zásobě mohou poukazovat na jistou vývojovou poruchu, proto zaujímá její mapování důležité místo $\mathrm{v}$ oblasti poradenské diagnostiky, terapie i prevence. Řada tuzemských odborníků (Lejska, 2003; Klenková, 2006; Neubauer, 2018; Preissová, 2013) jmenuje nedostatky $\mathrm{v}$ aktivním slovní zásobě jako jeden z průvodních symptomů vývojové dysfázie a věnuje jim proto pozornost v průběhu diagnostického procesu. V zahraniční, zejména anglosaské literatuře ovšem typicky není malý rozsah slovní zásoby řazen mezi diagnostické markery této poruchy (Conti-Ramsden \& Botting \& Faragher, 2001; Leonard, 2014), na což upozorňují i někteří čeští autoři (Smolík, 2009; Smolík \& Seidlová Málková, 2014). Na druhou stranu nelze říci, že by studium slovní zásoby dětí s vývojovou dysfázií zahraniční výzkum opomíjel; uvažování o významu lexikálních schopností v diagnostice dětí s vývojovou dysfázií lze opírat o výsledky řady zajímavých zahraničních výzkumů (Rice et al., 1992; Hick et al., 2002; Gray, 2003; Sheng \& McGregor, 2010; Laws et al., 2014; Vugs, 2016). Obecně lze říci, že v české odborné literatuře je v současné době k dispozici velmi malé množství studií zaměřených na povahu a strukturu lexikálních schopností českých dětí s vývojovou dysfázií (Vávrů, 2010; Dušková, 2010; Durdilová, 2014; Pilská, 2012). Specifickou hodnotu právě pro oblast poradenské i klinické praxe mohou pak mít zejména takové výzkumy, kde je možné sledovat slovní zásobu dětí s vývojovou dysfázií ve srovnání s typicky se vyvíjejícími dětmi.

Cílem této studie je proto porovnání rozsahu a kvality aktivní slovní zásoby u dětí s vývojovou dysfázií se stejně starými, intaktními dětmi. Konkrétně zjišt’ujeme, jak se liší kvantita produkované slovní zásoby i kvalita vyjadřování u dětí obou sledovaných skupin. V rámci popisných analýz rovněž usilujeme zachytit pro obě sledované skupiny charakteristické výkonové profily rozsahu slovní zásoby na úrovni vybraných slovních druhů: substantiv, verbií a adjektiv.

\section{Teoretická východiska}

\section{Vývojová dysfázie}

Vývojová dysfázie bývá popisována jako porucha jazykových schopností při normální nonverbální inteligenci, která postihuje přibližně 7,4 \% dětí (Tomblin et al., 1997). Jedná se o deficity v jazykovém vývoji bez zjevných přičin, kterými může být kupříkladu sluchová ztráta, mentální retardace, neurologické poškození nebo nedostatečný jazykový input (Bishop, 
2006; Dlouhá, 2017; Hulme \& Snowling 2009; Leonard, 2014; Tomblin et al., 1997). U vývojové dysfázie se nejedná o prosté opoždění jazykového vývoje, nýbrž o jeho narušení (Smolík, 2009).

Jazykové deficity se u vývojové dysfázie projevují na úrovni fonologické, gramatické i lexikální (Bishop, 2001; Dlouhá, 2017; Hulme \& Snowling, 2009; Leonard, 2014). Dle Leonarda (2014) jsou pro vývojovou dysfázii charakteristické značně heterogenní symptomy v oblasti jazykových schopností i deficity v jiných vývojových oblastech. Existují však dva prŕznaky, které jsou společné všem dětem s vývojovou dysfázií. Jedná se o specifické obtíže v morfologicko-syntaktické jazykové rovině, týkající se verbálního proevu i porozumění, a dále o specifické obtíže v rovině fonologické projevující se zejména při opakování. Diagnostické markery této poruchy lze tedy hledat v oblasti gramatiky a fonologie, nikoli v oblasti slovní zásoby. Dle Conti-Ramsen, Botting a Faraghera (2001) jsou vhodnými úlohami pro zachycení vývojové dysfázie test opakování pseudoslov a test opakování vět, které tyto problematické oblasti postihují. Dle Smolíka a Vávrů (2014) se ukazuje, že opakování vět je senzitivním markerem i pro české děti s vývojovou dysfázií. Dané úlohy se objevují i v zahraničním screeningovém testu pro zachycení vývojové dysfázie Grammar and Phonology Screening Test (Gardner et al., 2006).

\section{Lexikální schopnosti u dětí s vývojovou dysfázii}

Slovní zásoba má svou produktivní neboli aktivní (expressive vocabulary) a pasivní (receptive vocabulary) složku, přičemž pasivní slovník se v průběhu ontogeneze rozvíjí dříve než aktivní a zpočátku je také rozsáhlejší (Dlouhá, 2017; Hoff, 2014; Průcha, 2011; Smolík \& Seidlová Málková, 2014). Aktivní individuální slovník představuje slovní zásobu, kterou člověk aktivně užívá v rámci svých mluvených a písemných projevů. Pasivním individuálním slovníkem je pak míněna slovní zásoba, které jedinec rozumí, avšak aktivně ji neužíá (Karlík, Rusínová, \& Nekula, 1995). Zahraniční i tuzemské výzkumy (McGregor, 2002; Durdilová \& Klenková, 2014) upozorňují na to, že děti s vývojovou dysfázií vykazují oproti svým intaktním vrstevníkům deficity v oblasti aktivního i pasivního slovníku. Otázkou je, z jakého důvodu tyto deficity vznikají a jaký je jejich charakter.

Počáteční osvojování lexikálních schopností se nemusí u dětí s vývojovou dysfázií nikterak lišit. Dle Hicka et al. (2002) mají růstové křivky týkající se vzestupu rané slovní zásoby podobný charakter u dětí s vývojovou dysfázií i dětí intaktních. Některé výzkumy (Leonard et al., 1982; Weismer \& Hesketh, 1996) dokládají, že oblast slovní zásoby je u dětí s vývojovou dysfázií spíše vývojově opožděná než narušená. Dané studie totiž srovnávají výkony dětí s vývojovou dysfázií v předškolním či raném školním věku s výkony typicky se vyvíjejících dětí, mladších o jeden až dva roky. Docházejí tak k závěru, že při osvojování nových pojmů ani v preferenci určitých pojmů se neobjevují mezi uvedenými skupinami významné rozdíly. Rovněž tuzemský výzkum Petry Vávrů ${ }^{1}$ (2010) mluví o statisticky nevýznamných rozdílech ve slovní zásobě mezi skupinou předškolních dětí s vývojovou dysfázií a skupinou o dva roky mladších, běžně se vyvíjejících dětí. Zdá se tedy, že rozsah slovní zásoby není dostatečně

\footnotetext{
${ }^{1}$ Zde byla zkoumána pouze pasivní složka slovní zásoby na základě obrázkového slovníkového testu.
} 
citlivý ukazatel pro odlišení vývojové dysfázie a prostého opožděného vývoje jazykových schopností.

Objevují však i studie, které mluví o nižších výkonech dětí s vývojovou dysfázií týkající se některých aspektů slovní zásoby i ve srovnání s mladší intaktní populací. Například ve výzkumné studii Shenga a McGregora (2010) vykazovaly děti s vývojovou dysfázií oproti mladším dětem výraznější deficity $\mathrm{v}$ oblasti expresivního slovníku a dále u nich byla pozorována velká variabilita $\mathrm{v}$ lexikálně-sémantických organizačních schopnostech projevující se obtížemi při vyhledávání slov. Výzkum Laws a kol. (2014) dokládá, že sémantické znalosti slov se u dětí s vývojovou dysfázií a jejich intaktních vrstevníků nijak výrazně neliší, ačkoli $\mathrm{v}$ úlohách zaměřených na receptivní slovník, spočívajících $\mathrm{v}$ přiřazování týchž slov k obrázkům, podávají děti s vývojovou dysfázií horší výkon. Zdá se tedy, že dětem s vývojovou dysfázií činí některé aspekty z lexikálně-sémantické jazykové roviny větší potíže než jiné. Ukazuje se, že deficity dětí s vývojovou dysfázií v lexikálně-sémantické jazykové rovině spočívají především v učení se novým slovům („word learning“). Dle Rice, Buhr a Oettinga (1992) podávají děti s vývojovou dysfázií v učení se novým slovům podobné výkony jako mladší intaktní děti se srovnatelnou hodnotou indexu MLU (mean lenght of utterance, průměrné délky výpovědi ${ }^{2}$ ). Zároveň se ukazuje, že zvyšující se rychlost prezentování nových slov činí dětem s vývojovou dysfázií ještě větší obtíže než mladším dětem se srovnatelnou slovní zásobou (Weismer, Hesketh, 1996). Hulme a Snowling (2009) hovoří o obecných deficitech v rychlosti zpracování informací objevujících se u dětí s vývojovou dysfázií. Gray (2003) jmenuje specifika týkající se procesu učení se novým slovům u dětí s vývojovou dysfázií. V rámci svých výzkumů zjistila, že oproti běžným dětem potřebují děti s vývojovou dysfázií slyšet nové slovo dvojnásobně častěji a mít dvojnásobně více příležitostí $\mathrm{k}$ jeho procvičování, než jsou schopny jej použít samostatně.

Existují i tuzemské výzkumy zaměřené na problematiku aktivní slovní zásoby u dětí s vývojovou dysfázií. Většinou byly prováděny v rámci diplomových prací, což s sebou nese pochopitelné limity v možnostech velikosti výzkumného vzorku i v oblasti metodologie a zpracování dat. Dušková (2010) např. sledovala slovní zásobu dětí s vývojovou dysfázií ve třech věkových kategoriích (předškolní věk, 5 - 7 let, mladší školní věk, 7 - 11 a starší školní věk, 11 - 15 let), a to z hlediska výbavnosti z mentálního slovníku, strukturace slovní zásoby a významů slov. Výkony dětí s vývojovou dysfázií následně srovnávala s výkony stejně starých dětí intaktních. Ve všech sledovaných oblastech slovní zásoby vykazovaly děti s vývojovou dysfázií ve srovnání s dětmi intaktními nižší výkony, nejvýraznější rozdíly byly pozorovány v období předškolního věku. Durdilová a Klenková (2014) porovnávaly pasivní i aktivní slovník dětí s vývojovou dysfázií a jejich běžně vyvíjejících se vrstevníků pomocí Testu pasivní a aktivní slovní zásoby, při jehož tvorbě se inspirovaly zahraničním diagnostickým nástrojem: Comprehensive Receptive and Expresive Vocabulary Test (Wallace \& Hammill, 2013). Obě skupiny participantů vykazovaly vyšší úspěšnost v testech pasivního slovníku, v oblasti produkce i porozumění byl mezi výzkumnými skupinami shledán statisticky

\footnotetext{
${ }^{2}$ MLU je metoda navržená v sedmdesátých letech Rogerem Brownem (1973) pro hodnocení kvality spontánní řečové produkce dítěte. V českém prostř̌edí se prozatím využívá minimálně (Smolík, Seidlová Málková, 2011), v zahraničí, zejména ve USA, jde ale o hojně užívanou metodu v rámci logopedického vyšetření.
} 
významný rozdíl. Pilská (2012) pracovala s adaptací týchž zahraničních testi̊ a rovněž porovnávala výkony dětí s vývojovou dysfázií a dětí intaktních. Z výsledků výzkumu vyplynulo, že děti s vývojovou dysfázií měly oproti svým intaktním vrstevníkům výrazněji oslabené výkony v oblasti produkce (aktivního slovníku), než v oblasti porozumění (pasivního slovníku).

Dosavadní dostupné výzkumy s českými dětmi naznačují, že deficity v oblasti lexikálních schopností u dětí s vývojovou dysfázií existují, ale jejich závažnost i konkrétní podoba jsou dosti variabilní. I to je zřejmě důvodem, proč slovní zásoba nepředstavuje v kontextu diagnostického procesu oblast, v níž můžeme s jistotou hledat diagnostické markery vývojové dysfázie. Výzkum slovní zásoby u dětí s vývojovou dysfázií se tedy jeví jako potřebné a stále aktuální téma. Zvláště v českém prostředí, kde vývojová dysfázie představuje problematickou diagnózu, na jejímž pojetí nepanuje konsenzus, a pohled na etiologii, symptomatologii i diagnostiku této jazykové poruchy je stále nejednotný (Durdilová \& Klenková, 2014).

\section{Metodologie}

Výzkumné šetření, jehož závěry zde předkládáme, má deskriptivní a komparativní charakter. Jedná se o popis rozdílů $v$ rozsahu aktivní slovní zásoby a v kvalitě vyjadřování mezi skupinou intaktních dětí a skupinou dětí s vývojovou dysfázií.

\section{Průběh výzkumného šetření}

Realizace výzkumu probíhala ve dvou fázích, ve fázi pilotní/přípravné a ve fázi realizační. Př́pravná fáze výzkumu byla orientována na sestavování testového nástroje a jeho pilotní ověření. Probíhala v záŕí 2016. Pilotní šetření mělo za cíl prověřit nově vytvořený testový materiál $\mathrm{v}$ praxi, a to $\mathrm{u}$ zástupců $\mathrm{z}$ obou sledovaných skupin. Pro tyto potřeby bylo v mateřských školách osloveno 16 dětí (6 dětí s vývojovou dysfázií a 10 dětí intaktních), které nebyly následně zahrnuty do výzkumného souboru v realizační fázi. Na základě pilotního šetření byl následně konsolidován průběh testování, včetně způsobu dotazování se na položky a zaznamenávání odpovědí.

Realizační fáze výzkumu probíhala od října 2016 do května 2017 formou individuálního testování dětí v klidné místnosti v příslušných mateřských školách. Plnění celé testové procedury bylo rozděleno do dvou samostatných cca 30minutových setkání tak, aby se předcházelo únavě a nesoustředěnosti participantů. Administrace obou setkání byla vždy realizována v průběhu jednoho týdne.

\section{Charakteristika výzkumného vzorku}

Celkem 78 předškolních dětí bylo pro potřeby výzkumu rozděleno na dvě skupiny. Skupinu

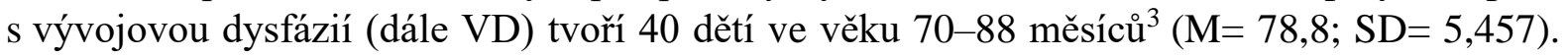

\footnotetext{
${ }^{3}$ Věkové rozpětí obou skupin participantů odpovídá věkovému rozpětí, v němž se nachází děti, které se následující školní rok chystají do první třídy. V důsledku toho, že u dysfatických i intaktních dětí
} 
Děti s diagnózou vývojová dysfázie byly vybírány bez současného výskytu jiné poruchy psychického vývoje, sluchového či neurologického postižení. Skupina VD se skládala z 9 dívek a 31 chlapců, což odpovídalo zjištěnému genderovému poměru výskytu této diagnózy (Hulme \& Snowling, 2009; Škodová \& Jedlička, 2006). Druhou sledovanou skupinu tvořily běžně se vyvíjející intaktní děti (dále INT) ve věku 71-88 měsíců ( $\mathrm{M}=78,5 ; \mathrm{SD}=4,072)$. Vzorek intaktních dětí byl sestaven tak, aby bylo genderové zastoupení participantů rovnoměrné a odpovídalo tak situaci v běžných předškolních výchovně vzdělávacích institucí. Skupinu INT původně tvořilo 20 dívek a 20 chlapců. Výkony dvou participantů však dle prvních popisných analýz nabývaly v oblasti rozsahu slovní zásoby extrémních hodnot, které jsme nedokázaly jednoznačně na podkladě dostupných informací vysvětlit a vyloučit tak chybu v procesu sběru dat. Data u skupiny INT jsou tedy analyzována na 18 chlapcích a 20 dívkách. Všichni participanti pochází z monoligvního jazykového prostředí, v němž je uživán český jazyk.

Vyhledávání participantů probíhalo $\mathrm{v}$ běžných mateřských školách a logopedických mateřských školách, eventuálně mateřských školách s logopedickými tř́ídami na území hlavního města Prahy. Skupina intaktních dětí byla sestavena na základě vyplněných informovaných souhlasů rodičů ze tří státních mateřských škol. Ve všech případech se jednalo o mateřské školy tzv. „sídlištního“ typu s větším počtem tříd. Děti s vývojovou dysfázií se podařilo získat pro výzkum (opět na základě informovaných souhlasů rodičů/zákonných zástupců) ve třech logopedických mateřských školách a jedné logopedické trrídě při mateřské škole pro žáky se sluchovým postižením.

\section{Metody sběru dat}

Klíčovým nástrojem pro sběr dat je v př́ípadě realizovaného výzkumu původní, pro potřeby studie sestavený, Test aktivní slovní zásoby.

\section{Skladba testu}

Test se skládá ze tří subtestů podle zkoumaných slovních druhů. Jedná se o subtest Substantiva (zaměřený na podstatná jména), subtest Verba (orientovaný na slovesa) a subtest Adjektiva (zkoumající př́ídavná jména). Celý test tvoří 45 položek, jeden subtest pak obsahuje 15 položek. Všechny 3 subtesty jsou členěny do 3 části s 5 testovými položkami, tyto části představují 3 různé typy operací se slovním materiálem: část Antonyma, část Definice a část Pojmenování v kontextu. Tato skutečnost naznačuje, že navržený test usiluje o zmapování širších lexikálně - sémantických jazykových schopností (tedy ne jen prostý úhrn lexémů, které sledovaný jedinec aktivně používá). Ukázky položek z jednotlivých subtestů uvádíme v př́lohovém materiálu.

Č́st Antonyma (viz př́loha) zkoumá schopnost chápat a vyjádřit opak ve verbální rovině naprríč zkoumanými slovními druhy. Skládá se z pojmů, jimž má participant určit opak. Kupř́íkladu v subtestu Verba je třeba určit opak slovesu „usínat“, v subtestu Substantiva má zkoumaná osoba vyřknout opak ke slovu „noc“ apod. V části Definice (viz prŕloha) jde

dochází k odkladu školní docházky, vyskytují se v rámci jednoho ročníku žáci, kteří mezi sebou mají věkový rozdíl více než rok. 
o vysvětlení významu pojmu; tedy např́klad v subtestu Adjektiva má participant vysvětlit, co znamená „hodný“، V části Pojmenování v kontextu (viz př́loha) je zjištována schopnost jedince kategorizovat pojmy dle prostředí či objekti̊, k nimž se vztahují. Tuto část doprovází u všech subtestů obrazový materiál, který usnadňuje evokaci kontextu př́slušné testové položky, z nichž je možné při jmenování vycházet. Přičemž je ale žádoucí překročit jejich rámec a jmenovat i objekty ( $\mathrm{v}$ subtestu Substantiva), činnosti (v subtestu Verba) a charakteristiky (v subtestu Adjektiva), které z daného obrázku nejsou patrné.

\section{Kritéria výběru testových položek}

Jednotlivé testové položky byly vybírány na základě souboru specifických kritérií. V první řadě šlo o možnost dané položky naplnit účel, $\mathrm{k}$ němuž je v rámci testu určena. V části Antonyma $\mathrm{u}$ všech subtestů bylo klíčové, aby k položce náleželo známé, tedy přibližně stejně nebo více frekventované antonymum nebo více antonym ${ }^{4}$. V části Pojmenování v kontextu v subtestech Verba a Substantiva bylo třeba vyhledat obrázky znázorňující jisté prostředí, k němuž se váží jisté typické objekty či činnosti a děje, přičemž některé z nich jsou na obrázku zachyceny. Vhodným podkladem se stala „Encyklopedie pro nejmenši““ (Babinová, 1993), tato sada obrázků byla doplněna ještě dvěma kresbami z knihy „Kdo tu bydlí““ (Zárubová, 1988). Pro část Pojmenování v kontextu v subtestu Adjektiva byly namalovány jednou z autorek sady obrázkových karet. K jednomu pojmu vždy náleží šest obrázků reprezentujících daný pojem $\mathrm{v}$ různých podobách.

Velmi důležitým kritériem pro výběr testových položek byla jejich korespondence s obsahem předškolního vzdělávání, které stanovuje Rámcový vzdělávací program pro předškolní vzdělávání (RVP PV). Východiskem byly Konkretizované očekávané výstupy RVP PV (2012), v nichž jsou v základních oblastech vzdělávání popsány pojmy, které má předškolní dítě znát a používat, a také jazykové schopnosti, kterých má dosahovat. Kupř́íkladu je zde uvedeno, že předškolní dítě má být schopno tvořit a chápat slova opačného významu, samostatně formulovat odpovědi a hovořit na určité téma.

Výběr testových položek se řídil také poměrem abstraktních a konkrétních pojmů. Rozlišování abstraktních a konkrétních pojmů je $\mathrm{v}$ daném testovém materiálu založeno na principu smyslové vnímatelnosti, který uvádí např. Čermák (2010). Položky v části Pojmenování v kontextu obsahují u všech subtestů pouze konkréta, ta je však možné popisovat pomocí abstraktních i konkrétních lexémů. Č́sti Antonyma a Definice zahrnují u všech subtestů $60 \%$ konkrétních a $40 \%$ abstraktních položek, a to i na úrovni základní pětice, představující jednu část konkrétního subtestu (např. část Definice v subtestu Adjektiva obsahuje položky: čistý, tichý, mokrý, hodný, protivný).

\footnotetext{
${ }^{4}$ Frekvence výskytu daných pojmů v českém jazyce byla určena na základě hodnoty i.p.m. (instances per milion), což je jednotka relativní frekvence vyjadřující průměrné množství výskytů daného slova $\mathrm{v}$ hypotetickém textu o délce 1 milion slov (Wiki Ceský národní korpus, [2017]). V současnosti vychází z korpusu SYN2015, což je synchronní a reprezentativní korpus současného psaného českého jazyka (Wiki Český národní korpus, [2017]).
} 


\section{Procedury pro zpracování výzkumného materiálu}

Testový materiál umožňuje hodnotit rozsah slovní zásoby i kvalitu vyjadřování. V těchto dvou rovinách bylo proto realizováno odlišné skórování.

\section{Hodnocení rozsahu aktivniho slovniku}

Test slovní zásoby sestavený pro potřeby této studie umožňuje sledovat rozsah slovní zásoby dítěte ze dvou perspektiv. $Z$ perspektivy slovních druhů (substantiva, verba, adjektiva), na něž cílí jednotlivé subtesty, a z perspektivy operací, které testované dítě s položkami provádí (určování antonym, definice slov, pojmenovávání v kontextu). Obě perspektivy lze také pro potřeby zhodnocení rozsahu slovní zásoby spojit a porovnávat výsledky v rámci jednotlivých slovních druhů $\mathrm{v}$ závislosti na prováděné operaci.

V části Antonyma a v části Definice byl u všech subtestů ke každé správné odpovědi přidělen 1 bod. Odpovědi v části Definice mohly být různě složité, což z hlediska hodnocení rozsahu slovníku nehrálo roli. Jednoslovná odpověd' zde tedy byla hodnocena stejně jako odpověd' ve formě souvětí, v obou př́padech k ní náležel 1 bod (např. odpověd’ na otázku „co znamená plakat?“" mohla znít: „,brečet“ anebo „když si pro mě máma nejde a já musím čekat ve školce, tak pláču“). Složitostí výpovědi v části Definice se zabývá až hodnocení kvality výpovědí, které je popsáno níže.

V části Pojmenování v kontextu bylo možné získat u každé položky více než 1 bod. Participanti zde získávali bod za každý lexém ve formě př́slušného slovního druhu, který se vztahoval k předkládané položce. Kupř́ikladu u položky „farma“"v subtestu Verba bylo možné na otázku „,co se dá dělat na farmě?“" odpovědět takto: ,pást koně, jezdit traktorem, zahradničit a zalévat"“. Taková odpověd' byla hodnocena 4 body, jelikož participant vyjmenoval 4 slovesa, která se vztahovala k danému kontextu.

Bodové hodnocení: Za část Antonyma lze získat maximálně 15 bodů ze všech částí subtestů (v každém subtestu je 5 položek, k nimž se mají určovat protiklady a subtesty jsou celkem tři). V části Definice je bodové hodnocení i počet položek v rámci všech subtestů stejný, tudíž i zde lze získat maximálně 15 bodů. Jak bylo vysvětleno v předchozím odstavci, maximální počet bodů získaných v části Pojmenování v kontextu nelze limitovat, závisí totiž na tom, kolik pojmů testované dítě $\mathrm{k}$ dané položce napadne. Horní hranice získaného počtu bodů za rozsah aktivního slovníku tedy zůstává otevřená.

\section{Hodnocení kvality vyjadřování}

Kvalitu vyjadřování sledujeme na podkladě části Definice ze všech př́slušných subtestů. Kvalitou vyjadřování je myšlena složitost formy výpovědi participanta. Na základě získaných odpovědí dětí z obou sledovaných skupin byly stanoveny čtyři druhy forem odpovědí: 1) odpověd' formou slova (např. „Co znamená voda?““ odpověd’ participanta: „Moře“); 2) odpověd’ formou více slov (např. „Co znamená hodný?““ odpověd’ dítěte: „Uklízí, nepere se.“); 3) odpověd’ formou věty (např. „Co znamená spěchat?“ odpověd’ dítěte: „Když běžíš na autobus.“) a 4) odpověd’ formou souvětí popř. více vět (např. „Co znamená tichý?““ odpověd’ dítěte: „Když jsme v divadle, musíme být potichu, abychom nerušili ostatní.“, nebo „Co znamená těšit se?“" odpověd’ dítěte: „Těším se, až přijde máma. Půjdeme totiž na zmrzlinu.“). V rámci našeho výzkumného vzorku jsme se nesetkaly s vyloženě nepřiléhavou odpovědí, 
která by značila neporozumění položce. Jinými slovy, pokud už participanti odpovídali, jejich vyjádření bylo vždy významově související vzhledem k předkládané položce. Pokud by však tato situace s nepřiléhavou odpovědí nastala, byla by evidována jako neporozumění a nehodnocena.

Bodové hodnocení: Kvalitu vyjadřování hodnotíme dle uvedených forem výpovědí následovně. Za odpověd' formou slova je udílen 1 bod, za odpověd' formou více slov 2 body, k odpovědi formou věty náleží 3 body, a pokud participant odpovídá souvětím či více větami, získá 4 body.

V rámci části Definice lze za kvalitu vyjadřování ze všech subtestů získat až 60 bodů. K jedné položce je možné získat maximálně 4 body a každý subtest obsahuje 5 položek, tedy v každém subtestu lze získat maximálně 20 bodů. Subtesty jsou tři, a pokud dítě získá v každém z nich maximální počet bodů, tedy 20 bodů, jeho celkové skóre v oblasti kvality vyjadřování bude činit 60 bodů.

\section{Výsledky výzkumu}

\section{Přehled rozdiliù v rozsahu a kvalitě slovní zásoby mezi výzkumnými skupinami}

Pro analytické zpracování získaného datového materiálu jsme pracovaly se statistickým softwarem IBM Statistics v. 25. Na úrovni všech dříve v testu popsaných aspektů produktivní slovní zásoby byla nejprve provedena deskriptivní statistika. Popisujeme tedy výsledky plnění úloh zaměřených na rozsah i kvalitu slovní zásoby, a to u obou sledovaných výzkumných skupin zvlášt'. Rozsah slovní zásoby zachycujeme jako celkový souhrnný výkon vyjadřující rozsah slovní zásoby, i dílčí skóre upřesňující rozsah slovní zásoby na úrovni podstatných jmen, sloves a př́idavných jmen. Přehled získaných údajů nabízí tabulka 1.

Tabulka 1. Deskriptivni statistika (průměr, směrodatná odchylka, rozpětí a medián); hodnoty pro rozsah a kvalitu slovní zásoby u obou sledovaných skupin.

\begin{tabular}{lcccccccc} 
& \multicolumn{4}{c}{ Skupina VD } & \multicolumn{5}{c}{ Skupina INT } \\
\cline { 2 - 9 } & Průměr & SD & Rozpětí & Medián & Průměr & SD & Rozpětí & Medián \\
\hline Rozsah SZ-celkovýskór & 96,23 & 5,92 & 150 & 100,0 & 114,82 & 4,04 & 97 & 119,50 \\
Rozsah SZ-substantiva & 42,95 & 2,67 & 66 & 46,00 & 46,26 & 1,81 & 45 & 47,50 \\
Rozsah SZ- verba & 28,55 & 1,93 & 48 & 29,50 & 36,68 & 1,36 & 33 & 36,50 \\
Rozsah SZ- adjektiva & 24,70 & 1,87 & 46 & 27,50 & 31,87 & 1,22 & 35 & 34,00 \\
Kvalita SZ & 23,93 & 2,05 & 47 & 26,0 & 38,97 & 2,25 & 46 & 39,50 \\
\hline
\end{tabular}

V tabulce 1 vidíme, že v celkovém rozsahu slovní zásoby dosahovala skupina VD v průměru asi o $16 \%$ nižšího skóre než skupina INT. Z perspektivy slovních druhů se ukazuje, že nejmenší rozdíl v rozsahu slovníku mezi výkony sledovaných skupin byl zaznamenán u podstatných jmen a odpovídá zhruba $7 \%$. V rozsahu slovní zásoby u sloves i př́́davných jmen podávaly intaktní děti již výrazněji lepší výkony oproti dětem s vývojovou dysfázií. 
V úlohách zaměřených na slovesa dosahovaly intaktní děti v průměru zhruba o $22 \%$ vyššího skóre a v úlohách, zaměřených na př́davná jména pak tento rozdíl činil asi $23 \%$. Z hlediska rozsahu slovní zásoby byl rozptyl dat shledán u obou skupin nejvyšší v př́padě podstatných jmen. U obou skupin lze také sledovat, že mezi slovesy a přídavnými jmény není př́liš velký rozdíl v naměřených hodnotách rozsahu slovní zásoby.

Ohledně kvality vyjadřování si můžeme všimnout (tabulka 1), že rozptyl dat je u obou skupin téměř stejný (u skupiny INT 46 bodů a u skupiny VD 47 bodů). Můžeme také vidět, že v oblasti kvality vyjadřování se mezi výzkumnými skupinami objevují větší rozdíly než v oblasti rozsahu slovní zásoby. Intaktní děti dosahují v kvalitě vyjadřování v průměru o více než $34 \%$ vyššího skóre než jejich vrstevníci s vývojovou dysfázií.

V rámci prvních analytických kroků jsme nejprve u obou sledovaných skupin a u všech sledovaných proměnných provedly test normality rozdělení dat (Kolmogorov-Smirnovův test). Testy rozložení dat u skupiny INT vyhodnocují jako normální rozdělení pouze distribuci u kvality slovní zásoby, rozsahu slovní zásoby - substantiva a rozsahu slovní zásoby - verba. Výkony skupiny VD jsou normálně rozdělené u všech sledovaných proměnných, kromě subtestu rozsah slovní zásoby - adjektiva. S přihlédnutím k charakteru rozdělení dat jsme proto pro porovnání výkonů obou sledovaných skupin použily Mann-Whitney neparametrický t-test. Výsledky tohoto testu pak prezentuje přehledně tabulka 2.

Tabulka 2. Rozdíly na úrovni rozsahu a kvality slovní zásoby mezi sledovanými skupinami VD a INT, Mann-Whitney test

\begin{tabular}{lll} 
& Mann-Whitney U & $\mathrm{p}$ (dvoustranný test) \\
\hline Rozsah SZ- celkový skór & -2.405 & $\mathbf{0 . 0 1 6}$ \\
Rozsah SZ-substantiva & -0.590 & 0.555 \\
Rozsah SZ-verba & -3.181 & $\mathbf{0 . 0 0 1}$ \\
Rozsah SZ- adjektiva & -2.829 & $\mathbf{0 . 0 0 5}$ \\
Kvalita SZ & -4.305 & $\mathbf{0 . 0 0 0}$ \\
\hline
\end{tabular}

Statisticky významné rozdíly ve výkonech skupiny VD a INT sledujeme u testu rozsahu i kvality slovní zásoby. Pokud posuzujeme test rozsahu slovní zásoby jako soubor tří odlišných subtestů (substantiva, verba a adjektiva), zaujme nás, že rozdíly ve výkonech mezi skupinami VD a INT nejsou statisticky významné u testu se substantivy.

\section{Analýza rozdílů výkonů v oblasti rozsahu slovní zásoby}

Konstatování statisticky významných rozdílů ve výkonech skupiny s vývojovou dysfázií a skupiny intaktních stejně starých dětí vhodně doplňuje grafické vyjádření distribuce výkonů pomocí histogramů (obrázek 1). Distribuce výkonů v testu rozsahu slovní zásoby u skupiny INT má sevřenější charakter než u skupiny s VD, pohybuje se v celkově menším výkonovém rozptylu a naznačuje, že všechny děti této skupiny zvládají test plnit alespoň na 62 bodů. Výkony dětí ze skupiny s VD naznačují, že v rámci této skupiny existují dvě výkonově odlišné podskupiny: děti, které se svými výkony přibližují intaktní skupině a dále děti s velmi slabými výkony, které nedosahují úrovně nejslabších výkonů ve skupině INT. 

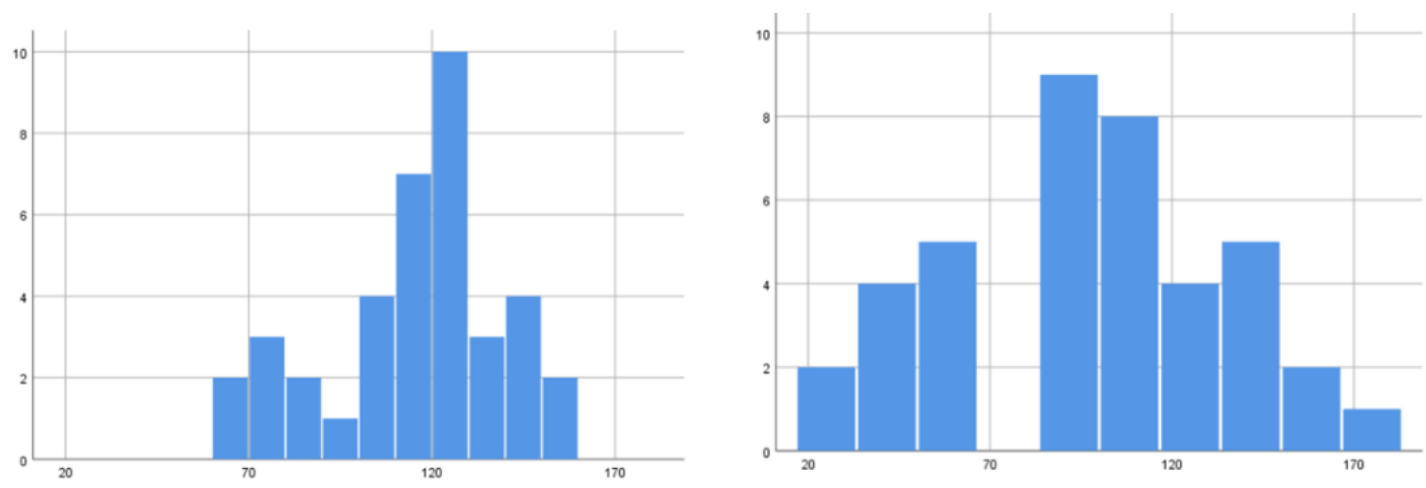

Obrázek 1. Histogramy pro rozsah slovní zásoby - celkový skór; vlevo distribuce výkonů skupiny INT, vpravo distribuce výkonů skupiny VD (na vodorovné ose vždy dosažené skóre v testu, na svislé ose vždy počet participantü).

Při analýze rozdílů $\mathrm{v}$ rozsahu slovní zásoby $\mathrm{z}$ hlediska zkoumaných slovních druhů se „bimodální“ charakter rozložení dat u skupiny VD nejvýrazněji ukázal u substantiv (obrázek 2). Naopak při vizualizaci dat týkajících se rozsahu slovní zásoby u verb lze pozorovat jakousi křivku typickou pro normální rozložení, která je velmi podobná u obou skupin participantů. Charakter výkonů v oblasti rozsahu slovní zásoby se tedy mezi výzkumnými skupinami nejméně liší $\mathrm{v}$ př́ípadě sloves a nejvíce $\mathrm{v}$ príípadě podstatných jmen, což lze pozorovat $\mathrm{i}$ v souvislosti s průměrnými skóry a mediány (viz tabulka 1).
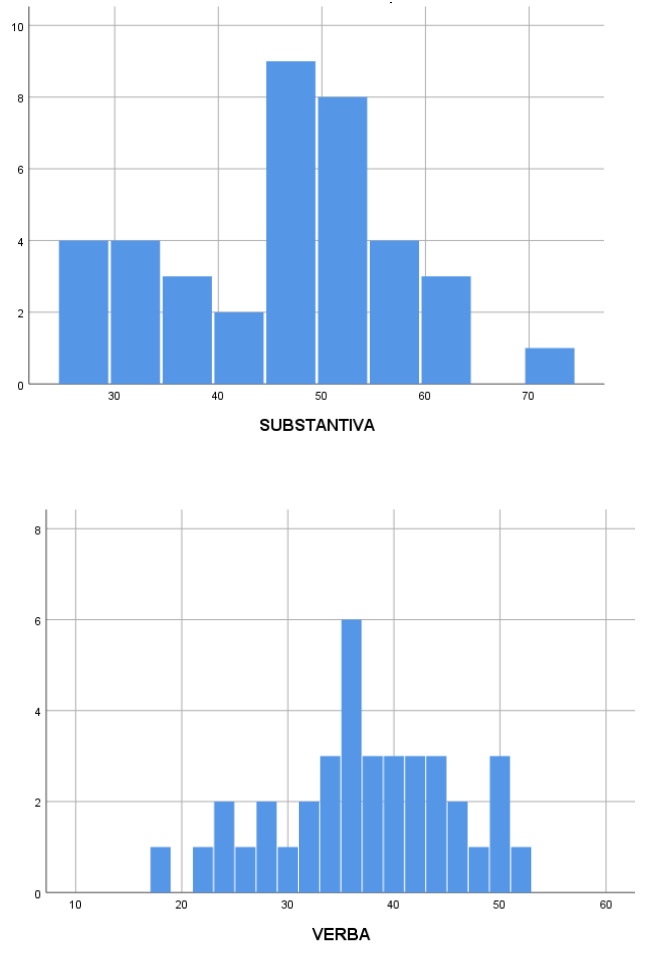
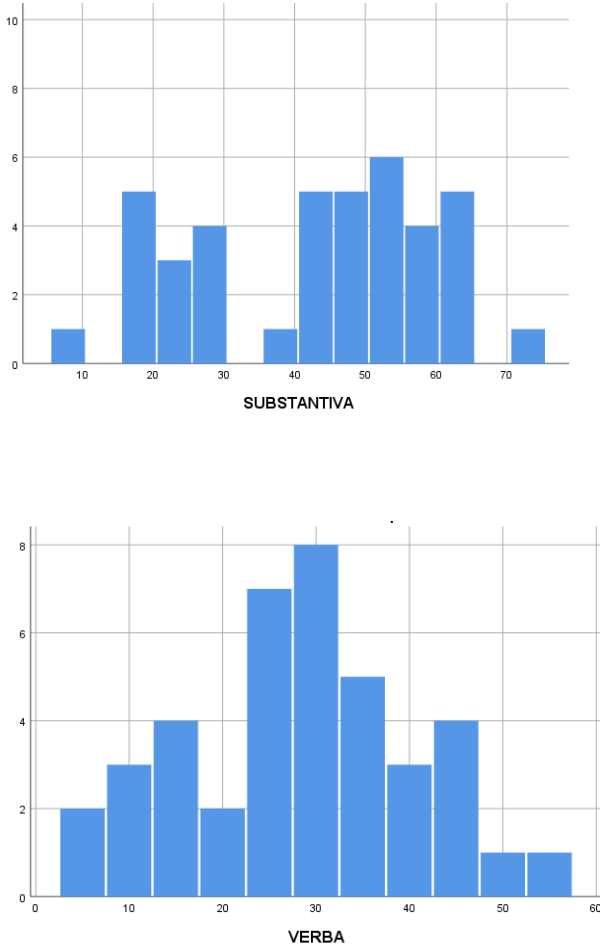

Obrázek 2. Histogramy pro rozsah slovni zásoby u podstatných jmen a sloves - vlevo výkony skupiny INT, vpravo výkony skupiny VD, nahoře podstatná jména, dole verba (na vodorovné ose vždy dosažené skóre v testu, na svislé ose vždy počet participantů). 


\section{Analýza rozdílů výkonů v kvalitě vyjadřování}

V oblasti kvality vyjadřování bylo možné dosáhnout až 60 bodů. Takový výsledek by znamenal, že dítě odpovědělo na všech 15 položek sytících celkový skór kvality vyjadřování souvětím nebo pomocí více vět. K tomuto celkovému skóre se svým výkonem přiblížilo 6 dětí ze skupiny INT s počtem 58 bodů. Nejvyšší dosažené skóre ve skupině VD činilo 47 bodů a povedlo se jej dětem dosáhnout ve 3 př́ípadech. Ve skupině s VD najdeme děti, které úlohu nezvládají plnit téměř vůbec, ve skupině INT byla nejnižší získaná bodová hodnota 12 .

Na úrovni kvality vyjadřování pozorujeme celkově nižší výkony u skupiny VD než u skupiny INT, pro obě skupiny ale platí přibližně stejný rozsah výkonového rozptylu (u skupiny INT 46 a u skupiny VD 47 bodů). Rozptyl dat týkající se kvality lze porovnat s rozptylem dat naměřených u rozsahu slovní zásoby v rámci obou výzkumných skupin, to umožňuje obrázek 3. Je patrné, že zatímco u skupiny VD je rozptyl dat v oblasti kvality vyjadřování i rozsahu slovní zásoby poměrně velký, u skupiny INT je rozptyl dat podstatně širší v oblasti kvality vyjadřování.
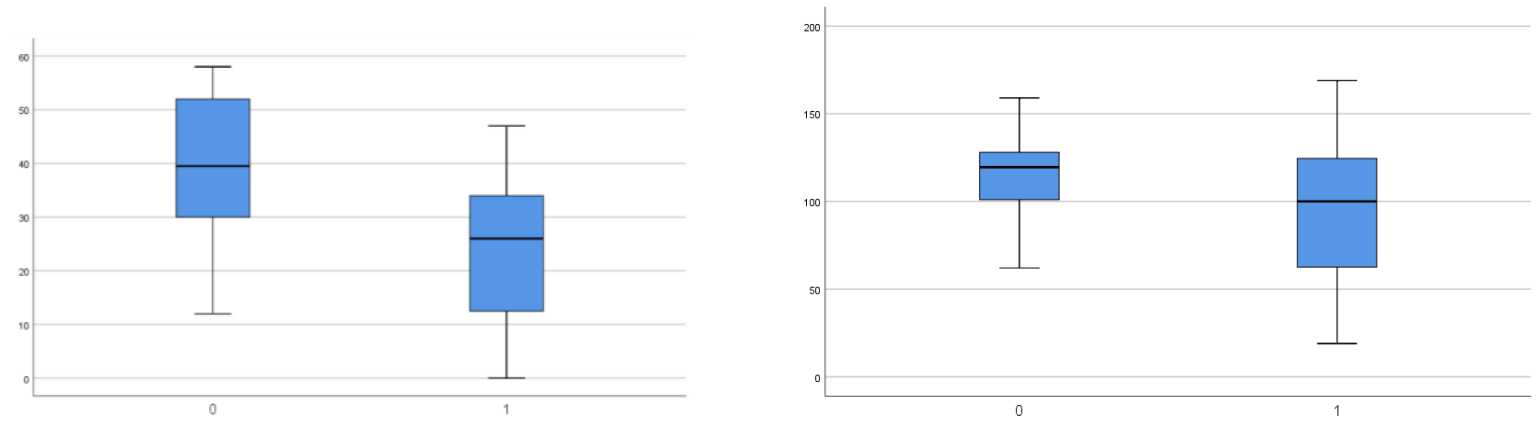

Obrázek 3. Kvartilový graf pro kvalitu vyjadřování (vlevo) a pro rozsah slovni zásoby (vpravo), graf umistěný v levém sloupci a označený „0“ představuje v obou prípadech skupinu INT, graf označený „1“ skupinu VD.

Odpovědi intaktních dětí měly nejčastěji podobu věty nebo souvětí, popř. více vět. Děti s vývojovou dysfázií se naproti tomu vyjadřovaly nejčastěji formou jednoho slova a formu souvětí či více vět používaly nejméně (viz obrázek 4). Můžeme si ale také všimnout, že odpověd' formou věty se vyskytovala u obou skupin participantů ve srovnatelném množství. Mezi čtyřmi zaznamenanými typy odpovědí lze nalézt dva, které nedosahují syntaktické úrovně (slovo a více slov) a dva, které této úrovně dosahují. $Z$ tohoto hlediska lze říci, že skupina VD odpovídala na syntaktické úrovni v $40 \%$ př́padů a skupina INT této úrovně dosahovala v $65 \%$ př́padů. 

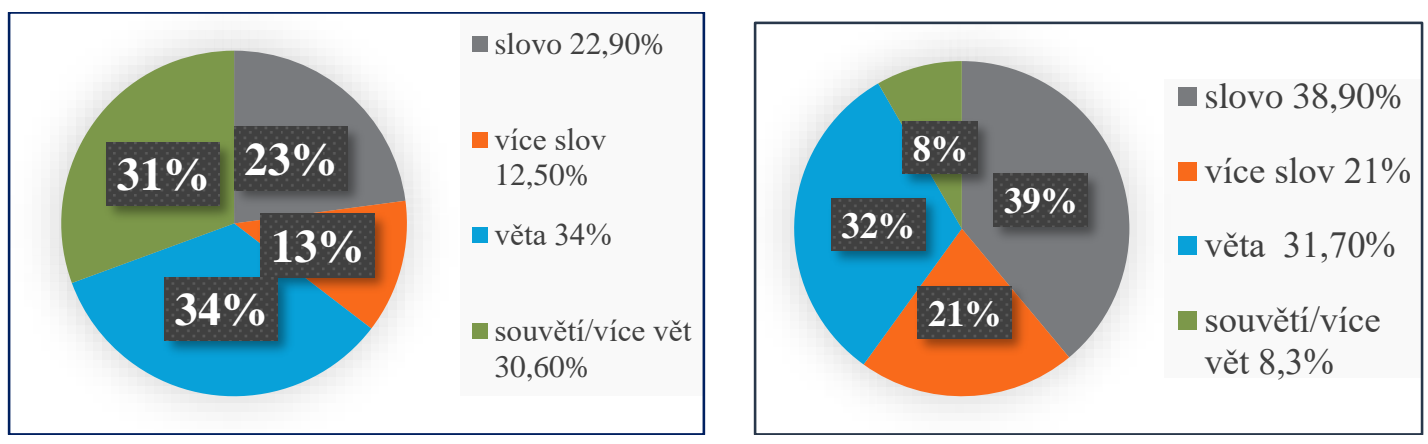

Obrázek 4. Kruhové diagramy pro vyjádřeni poměru typu odpovědi dle kvality vyjadřování, vlevo skupina INT, vpravo skupina VD.

\section{Shrnutí výsledků výzkumu a diskuse}

V oblasti rozsahu slovní zásoby i v oblasti kvality vyjadřování byly zjištěny statisticky významné rozdíly mezi skupinami INT a VD. Z hlediska slovních druhů byl zaznamenán nejnižšś rozdíl v rozsahu slovní zásoby mezi výzkumnými skupinami v subtestu zaměřeném na substantiva, který sám o sobě nezachytil statisticky významné rozdíly mezi dětmi s vývojovou dysfázií a dětmi intaktními. Naopak největší rozdíl v rozsahu slovní zásoby mezi výzkumnými skupinami byl naměřen u adjektiv. V oblasti kvality vyjadřování se výkony dětí s vývojovou dysfázií liší od jejich intaktních vrstevníků ještě výrazněji než v oblasti rozsahu slovní zásoby. U obou výzkumných skupin však získaná data, týkající se kvality vyjadřování, vykazují poměrně velký rozptyl.

V rámci analytických šetření rozsahu slovní zásoby byly zjištěny dvě zajímavé skutečnosti. První takovou skutečností je charakter rozložení výkonů u skupiny VD. Zdá se, že v rámci celé skupiny dětí s VD se objevuje značné rozpětí výkonů v oblasti slovní zásoby, což umožňuje v podstatě rozlišovat dvě výkonově odlišné „,podskupiny“ VD dětí (viz „,bimodální“ charakter rozložení dat v obrázku 1). Zatímco jedna podskupina vykazovala výkony velmi blízké nebo dokonce identické s dětmi intaktními, druhá podskupina podávala $\mathrm{v}$ testu velmi slabé výkony, nedosahující ani nejnižších výkonů skupiny INT. Otázkou je, do jaké míry je tato zjištěná skutečnost důsledkem nejasných diagnostických kritérií vývojové dysfázie v našem prostředí a do jaké míry vypovídá o tom, že příčinné mechanismy vývojové dysfázie se mohou $\mathrm{v}$ jednotlivých jazykových oblastech manifestovat různě silně a vytvářet tak jakési podtypy vývojové dysfázie. Existují studie, které takové subtypy vývojové dysfázie popisují (Miklošová \& Mikulajová, 2014). Dle Snowling a kol. (2015) se však ukazuje, že rozdíly mezi dětmi s vývojovou dysfázií spočívají spíše v míře celkového jazykového deficitu, nežli ve větším či menším narušení určitých dílčích jazykových oblastí. Jednotlivé jazykové aspekty jsou totiž v systému jazyka propojeny a vzájemně se ovlivňují. V př́padě vývojové dysfázie jsou deficity voblasti slovní zásoby patrně důsledkem hlubších deficitů v oblasti tzv. diagnostických markerů vývojové dysfázie, jimiž jsou deficity v krátkodobé fonologické paměti a deficity v gramatické kompetenci. Souvislost mezi deficity v oblasti pracovní paměti a lexikálními schopnostmi můžeme vysvětlit tím, že děti s vývojovou dysfázií mají problém současně ukládat a zpracovávat verbální informace, a to je omezuje v nabývání jazykových 
dovedností včetně rozvoje slovní zásoby (Vugs et al., 2016). Na propojení lexikálních a gramatických schopností poukazuje tzv. syntaktický bootstrapping, tedy pochopení významu neznámých slov na základě gramatického kontextu, v němž se nachází (Naigles, 1990).

Druhou zajímavou zjištěnou skutečností je absence statisticky významných rozdílů skupiny s VD a INT ve výkonech v testu rozsahu slovní zásoby v subtestu zaměřeného na substantiva. Toto zjištění lze vysvětlit $\mathrm{z}$ vývojového hlediska. Vzhledem $\mathrm{k}$ tomu, že děti $\mathrm{v}$ našem jazykovém prostředí začínají používat substantiva zpravidla dříve než verba či adjektiva, bývají již v době před zahájením školní docházky dobře osvojené i u dětí s vývojovou dysfázií. Osvojení zbylých dvou zkoumaných slovních druhů ještě v tomto věku nemusí být u dětí s VD dostatečně konsolidované, a proto se v nich výrazněji projevují odchylky ve slovní zásobě od běžně se vyvíjející populace. Lze tedy konstatovat, že zaměření testu na více slovních druhů je vhodně zvoleným postupem při konstrukci screeningového nástroje k posuzování rozsahu slovní zásoby.

Z hlediska kvality vyjadřování nás zaujal poměrně značný rozptyl dat u obou sledovaných skupin. Zdá se, že tento jazykový aspekt zatím není ani u jedné z výzkumných skupin konsolidován a bude se patrně ještě nadále vyvíjet $v$ průběhu školního věku. Jistě by bylo př́nosné zaměřit se na kvalitu vyjadřování z vývojového hlediska a zkoumat ji u obou skupin participantů až do pozdějších let. Na druhou stranu se ukazuje, že hodnocení kvality vyjadřování vhodně doplňuje hodnocení rozsahu slovní zásoby, nebot' mezi výsledky z obou těchto oblastí byl shledán velmi těsný korelační vztah. Lze tedy předpokládat, že dítě, které tvoří jednodušší formy výpovědí, bude mít nižší rozsah slovní zásoby a naopak.

Z hlediska metodologického by mohlo nepochybně být zajímavé předložení daných testových materiálů ještě další výzkumné skupině, kterou by tvořily intaktní děti mladšího věku, představující nižší úroveň jazykových schopností. Jejich výkony v komparaci s výkony skupiny s VD by mohly naznačit, které zkoumané aspekty lexikálních schopností jsou pro děti s vývojovou dysfázií zvláště obtížné.

\section{Závěr}

Výsledky této studie mohou svými závěry a předloženým datovým materiálem přispět k efektivnějšímu a cílenému využití diagnostiky slovní zásoby předškoláků s VD před nástupem do prvního ročníku základní školy. Ukazuje se, že v tomto věkovém období lze vývojové deficity v oblasti slovní zásoby identifikovat dostačujícím způsobem i jen na základě údajů o rozsahu slovní zásoby dítěte (bez nutnosti zabývat se kvalitou vyjadřování dítěte). Citlivě v tomto období rozměr prrípadných vývojových deficitů zachycují především položky sestavené a cílené na zacházení se substantivy. Zároveň ale platí, že administrace testových úloh umožňujících odlišení kvality produkce slovní zásoby i na úrovni dalších slovních druhů (substantiva a adjektiva), může pomoci zpřesnit a zacílit případný intervenční plán pro práci s dítětem.

Test slovní zásoby, který byl v této studii představen, považujeme za vhodný pro další potenciální využití v praxi. Předpokládáme ale, že pro širší užití tohoto materiálu je třeba jej i na základě výsledků předložené studie - upravit a uzpůsobit tak, aby mohl dobře a efektivně sloužit diagnostickému procesu v poradenské či klinické praxi. Výkony dětí srovnávací 
skupiny (intaktní děti) také naznačují, že by mohl být využíván i jako screeningový nástroj pro základní posouzení jazykových schopností v rámci vyšetření školní zralosti.

Tato studie vznikla v rámci řešení projektu PedF UK „Diagnostické markery v českém jazykovém prostředi “ podpořeného GAUK (̌̌. 251209) pro období 2019-2021.

\section{Literatura}

Bishop, D. V. (2006). What causes specific language impairment in children? Current Directions in Psychological Science, 15(5), 217-221. https://doi.org/10.1111/j.14678721.2006.00439.x

Brown, R. (1973). A first language: The early stages. Cambridge: Harvard University Press.

Caravolas, M., Lervåg, A., Mikulajová, M., Defior, S., Seidlová-Málková, G., \& Hulme, C. (2019). A cross-linguistic, longitudinal study of the foundations of decoding and reading comprehension ability. Scientific Studies of Reading, 23(5), 386-402. https://doi.org/10.1080/10888438.2019.1580284

Conti-Ramsden, G., Botting, N., \& Faragher, B. (2001). Psycholinguistic markers for specific language impairment (SLI). Journal of Child Psychology and Psychiatry, 42(6), 741748. https://doi.org/10.1111/1469-7610.00770

Dlouhá, O. (2017). Poruchy vývoje řeči. Praha: Galén.

Durdilová, L., \& Klenková, J. (2014). Hodnoceni slovni zásoby dètí před zahájením školní docházky = The lexicon evaluation of children before their enrolling in school. Praha: Univerzita Karlova v Praze, Pedagogická fakulta.

Dušková, L. (2010). Porovnání výkonnosti ve slovníkové zkoušce u dětí a žákůs vývojovou dysfázií a ziskanou afázií. Diplomová práce. Praha: Univerzita Karlova, Pedagogická fakulta.

Gardner, H., Froud, K., McClelland, A., \& van der Lely, H. K. J. (2006). Development of the Grammar and Phonology Screening (GAPS) test to assess key markers of specific language and literacy difficulties in young children. International Journal of Language \& Communication Disorders, 41(5), 513-540. https://doi.org/10.1080/13682820500442644

Gray, S. (2003). Word-learning by preschoolers with specific language impairment. Journal of Speech, Language, and Hearing Research, 46(1), 56-67. DOI: 1044/10924388(2003/005)

Hick, R. F., Joseph, K. L., Conti-Ramsden, G., Serratrice, L., \& Faragher, B. (2002). Vocabulary profiles of children with specific language impairment. Child Language Teaching and Therapy, 18(2), 165-180. https://doi.org/10.1191/0265659002ct233oa

Hoff, E. (2014). Language development. Belmont: Wadsworth/Thomson Learning.

Karlík, P., Nekula, M., \& Rusínová, Z. (1995). Příruční mluvnice češtiny. Praha: Nakladatelství Lidové noviny.

Klenková, J. (2006). Logopedie: Narušení komunikační schopnosti, logopedická prevence, logopedická intervence $v \check{C} R$, př́klady z praxe. Praha: Grada.

Laws, G., Briscoe, J., Ang, S., Brown, H., Hermena, E., \& Kapikian, A. (2014). Receptive vocabulary and semantic knowledge in children with SLI and children with Down syndrome. Child Neuropsychology, 21(4), 490-508. https://doi.org/10.1080/09297049.2014.917619

Lejska, M. (2003). Poruchy verbálni komunikace a foniatrie. Brno: Paido. 
Leonard, L. B. (2014). Children with specific language impairment. Cambridge: MIT Press.

Leonard, L. B., Schwartz, R. G., Chapman, K., Rowan, L. E., Prelock, P. A., Terrell, B., Weiss, A. L, \& Messick, C. (1982). Early lexical acquisition in children with specific language impairment. Journal of Speech, Language, and Hearing Research, 25(4), 554564. https://doi.org/10.1044/jshr.2504.554

McGregor, K. K., Newman, R. M., Reilly, R. M., \& Capone, N. C. (2002). Semantic representation and naming in children with specific language impairment. Journal of Speech, Language, and Hearing Research, 45(5), 998-1014. DOI:10.1044/10924388(2002/081)

Miklošová, I. \& Mikulajová, M. (2014). Longitudinálne sledovanie jazykovo-kognitívnych schopností detí s narušeným vývinom reči a ich intaktných rovesníkov. Logopaedica XVII, 18 (1), 11-25.

Naigles, L. (1990). Children use syntax to learn verb meanings. Journal of Child Language, 17(2), 357-374. https://doi.org/10.1017/s0305000900013817

Neubauer, K. (2018). Kompendium klinické logopedie: Diagnostika a terapie poruch komunikace. Praha: Portál.

Pilská, H. (2012). Hodnoceni slovní zásoby u dětí předškolního věku se specificky narušeným vývojem řeči. Diplomová práce. Praha: Univerzita Karlova, Pedagogická fakulta.

Průcha, J. (2011). Dětská řeč a komunikace: Poznatky vývojové psycholingvistiky. Praha: Grada.

Preissová, I. (2013). Vývojové poruchy řeči. Pediatrie pro praxi, 14(4), 242-243.

Reilly, S., Tomblin, B., Law, J., McKean, C., Mensah, F. K., Morgan, A., Goldfeld, S., Nicholson, J. M., \& Wake, M. (2014). Specific language impairment: A convenient label for whom? International Journal of Language \& Communication Disorders, 49(4), 416451. https://doi.org/10.1111/1460-6984.12102

Rice, M. L., Buhr, J., \& Oetting, J. B. (1992). Specific-Language-Impaired Children's Quick Incidental Learning of Words. Journal of Speech, Language, and Hearing Research, 35(5), 1040-1048. https://doi,org/10.1044/jshr.3505.1040

Seidlová Málková, G. \& Smolík, F. (2014). Vývoj jazykových schopností. Praha: Grada.

Sheng, L., \& McGregor, K. K. (2010). Lexical-semantic organization in children with specific language impairment. Journal of Speech, Language, and Hearing Research, 53(1), 146-159. DOI: 10.1044/1092-4388(2009/08-0160)

Smolík, F., \& Vávrů, P. (2014). Sentence imitation as a marker of SLI in Czech: Disproportionate impairment of verbs and clitics. Journal of Speech, Language, and Hearing Research, 57(3), 837-849. doi:10.1044/2014_jslhr-1-12-0384

Smolík, F., \& Málková Seidlová, G. (2011). Validity of language sample measures taken from structured elicitation procedures in Czech. Československá psychologie, 55(5), 448458.

Smolík, F. (2009). Vývojová dysfázie a struktura raných jazykových schopností. Československá psychologie, 53(1), 40-54.

Smolíková, K. (2004). Rámcový vzdělávací program pro předškolní vzdělávání. Praha: Výzkumný ústav pedagogický.

Snowling, M. J., \& Hulme, C. (2009). Developmental disorders of language learning and cognition. Chicester: Wiley.

Snowling, M. J., Duff, F. J., Nash, H. M., \& Hulme, C. (2015). Language profiles and literacy outcomes of children with resolving, emerging, or persisting language impairments. Journal of Child Psychology and Psychiatry, 57(12), 1360-1369. https://doi.org/10.1111/jcpp.12497 
Škodová, E. \& Jedlička, I. (2007). Klinická logopedie. Praha: Portál.

Tomblin, J. B., Records, N. L., Buckwalter, P., Zhang, X., Smith, E., \& O’Brien, M. (1997).

Prevalence of specific language impairment in kindergarten children. Journal of Speech, Language, and Hearing Research, 40(6), 1245-1260.

https://doi.org/10.1044/jslhr.4006.1245

Vávrů, P. (2010). Specifické symptomy vývojové dysfázie. Diplomová práce. Praha: Univerzita Karlova, Filozofická fakulta.

Vugs, B., Knoors, H., Cuperus, J., Hendriks, M., \& Verhoeven, L. (2016). Interactions between working memory and language in young children with specific language impairment (SLI). Child Neuropsychology, 22(8), 955-978. https://doi.org/10.1080/09297049.2015.1058348

Wallace, G., \& Hammill, D. D. (2013). Comprehensive Receptive and Expressive Vocabulary Test-(CREVT-3) Austin: Pro-Ed Inc.

Weismer, S. E., \& Hesketh, L. J. (1996). Lexical learning by children with specific language impairment: Effects of linguistic input presented at varying speaking rates. Journal of Speech, Language, and Hearing Research, 39(1), 177-190.

https://doi.org/10.1044/jshr.3901.177

\section{PŘÍLOHOVÝ MATERIÁL:}

Ukázka položek a odpovédí použitého testu:

\begin{tabular}{|c|c|c|c|l|}
\hline Subtest & Část subtestu & Příklad položky & Otázka k položce & Odpověd' dítěte (př́íklad) \\
\hline Adjektiva & Antonyma & Veselý & Jaký je opak veselého? & Smutný \\
\hline Adjektiva & Antonyma & Dlouhý & Jaký je opak dlouhého? & Krátký \\
\hline Substantiva & Definice & Voda & Co to znamená voda? & Koupat \\
\hline Substantiva & Definice & Radost & Co to znamená radost? & Když přijde máma domů \\
\hline Verba & $\begin{array}{c}\text { Pojmenování } \\
\text { v kontextu }\end{array}$ & Farma & Co se dělá na farmě? & $\begin{array}{l}\text { Jezdí traktorem, krmí slepice, } \\
\text { seká tráva, suši se seno }\end{array}$ \\
\hline Verba & $\begin{array}{c}\text { Pojmenování } \\
\text { v kontextu }\end{array}$ & Nemocnice & Co se dělá v nemocnici? & Ošetřuje se, operuje se \\
\hline
\end{tabular}




\section{Údaje o autorkách}

Mgr. Alžběta Větrovská Zemánková je doktorandkou na Katedře psychologie Pedagogické fakulty Univerzity Karlovy. Zabývá se problematikou vývoje jazykových schopností, jeho diagnostikou a patologií, zejména pak v oblasti vývojové dysfázie.

\section{Kontaktní údaje}

Adresa: Katedra psychologie PedF UK, Myslíkova 7, 11000 Praha 1

E-mail: lasice.kolcava@email.cz

Doc. PhDr. Gabriela Seidlová Málková, Ph.D. působí na Katedře psychologie a věd o životě Fakulty humanitních studií Univerzity Karlovy a na Katedře psychologie Pedagogické fakulty Univerzity Karlovy. Ve výzkumu se věnuje zejména otázkám raného vývoje gramotnosti; významu fonologických a dalších jazykových schopností pro rozvoj počátečního čtení a psaní.

\section{Kontaktní údaje}

Adresa: Katedra psychologie a věd o životě FHS UK, Pátkova 2137/5, 18200 Praha 8 E-mail: gabriela.malkova@fhs.cuni.cz

Větrovská Zemánková, A., \& Seidlová Málková, G. (2020). Studie verbální produkce českých předškolních dětí s vývojovou dysfázií. E-psychologie, 13(3), 31-48.

https://doi.org/10.29364/epsy.377 